\title{
The POWERful TRANSFORMATION OF THE YOUNG MAN IN MARK 14:51-52 AND 16:5
}

Author:

Pieter G.R. de Villiers ${ }^{1}$

\section{Affiliation:}

${ }^{1}$ Department New

Testament, University of

the Free State,

South Africa

\section{Correspondence to: \\ Pieter de Villiers}

email:

pgdevilliers@mweb.co.za

Postal address:

Department New

Testament, University

of the Free State,

Bloemfontein 9300,

South Africa

\section{Keywords:}

biblical spirituality; Mark 14:51-52; Mark 16:5; the young man in Mark; transformation

\section{Dates:}

Received: 23 Jan. 2010

Accepted: 08 June 2010

Published: 05 Nov. 2010

How to cite this article:

De Villiers, P.G.R.

2010, 'The powerful

transformation of the

young man in Mark 14:51-

52 and 16:5', HTS Teologiese

Studies/Theological Studies

66(1), Art. \#893, 7 pages.

DOI: $10.4102 /$ hts.v66i1.893

\section{This article is available} at:

http://www.hts.org.za

(c) 2010. The Authors.

Licensee: OpenJournals

Publishing. This work

is licensed under the

Creative Commons

Attribution License.

\section{ABSTRACT}

This article investigates the references to the young man in two different, but related episodes in Mark 14:51-52 and 16:5. First of all, it clarifies some exegetical questions in the two sections. It then analyses the history of the interpretation of the young man in these two passages before it discusses the nature of the coherence between the two passages in greater detail. To this end, the article investigates shared motifs in the two narratives in the light of Mark's literary techniques. Finally, it compares the two episodes of the young man with the healing of the demoniac in Mark 5, in order to reflect on the implications of reading these two passages together. These implications are spelled out in terms of the powerful notion of transformation - a key theme in biblical spirituality and central in Mark's thought. This notion is developed as transformation in recreation, love and glory.

\section{INTRODUCTION}

The passage about Jesus' night of prayer in Gethsemane and his eventual arrest (Mk14:32-51) ends in a cryptic description of an anonymous young man who 'was following Jesus' and who flees the scene as he, too, is accosted. The young man has not been mentioned previously in the gospel. The enigmatic episode contains the most basic of information, thus failing to illuminate it in more detail: the author mentions that the young man wears nothing but a linen garment which he, as Jesus is seized, leaves behind while fleeing from the scene. He then, according to most interpreters, disappears from the scene, not to be mentioned in the gospel again.

There is, however, one other reference in Mark's Gospel, equally enigmatic, to a similar character. The climactic description of the women's discovery of the empty tomb also refers to a young man. In Mark 16 , the women go to Jesus' tomb early on the sabbath after his death, worrying about how they will get to the body of Jesus to anoint it. They discover that the stone has been rolled away and then find a young man dressed in a white robe sitting on the right side, who tells them about the resurrection of Jesus. Scholars tend to regard this young man as a new character in the narrative, not to be linked with the young man in the garden of Gethsemane.

These two passages have been subjected to several investigations, as need to be explained now in more detail.

\section{HISTORY OF INTERPRETATION OF THE YOUNG MEN IN MARK 14:51-52} AND MARK 16:1-8

Attempts to make sense of the episode of the young man in the garden vary between a literal or symbolic approach (cf. e.g. Brown 1994:294-302). On the one hand, some scholars have tried to identify the young man as a historical figure ${ }^{2}$ like John Mark ${ }^{3}$, the author of the gospel (Blaiklock 1967:9-10) ${ }^{4}$ or, more generally, an eyewitness. ${ }^{5}$ The most recent contribution in this regard comes from Bauckham (2007:197-198) who argues that the young man was an eyewitness who followed Jesus after the rest of the disciples had abandoned him. He observes and is therefore later able to report what actually happened when Jesus was arrested in the garden. The reality of the event is, amongst others, according to Bauckham, indicated by such concrete information as the naked flight of the young man. Such events are reported in ancient texts, which show that abandoning one's coat was not unusual and therefore need not be understood symbolically.

Other exegetes, on the other hand, tend to read the story symbolically. They argue, for example, that the author narrated this event to express the fulfilment of Scripture in the life of Jesus. They then read the story of the young man in the light of the passage in Amos 2:16 about the strongest soldier who will flee naked in the future. ${ }^{6}$

\section{For exegetical issues, cf. Collins (2007:123).}

2.The thesis that the young man was an eyewitness is popular; cf. for example Saunderson (1989). Haren (1998:525-531) identifies him as Lazarus. Bauckham (2007:200) rightly finds this thesis appealing, but impossible to prove. For other proposals, cf. Brown (1994:294).

3.Brown (1994:299) rejected attempts to identify John Mark as the young man as being imaginative flights of fancy.

4.Cf. the references to John Mark in Philemon 24; Colossians 4:10; 1 Peter 5:13; Acts 12:25; 13:13; 15:36-41.

5.For example Schweitzer (1968:316-317): Lane (1974:527). For a full discussion, cf. Brown (1994:302) who points out that the clothing aspect of baptism by immersion is late. In the later imagery, the one who is baptised divests clothes to be with Christ, not to get away from him, as in Mark 14.

6.For example Klostermann (1950:153); Lane (1974:527). 
There is, however, another interesting development in which a more complex reading of the passage is developed. It is especially in such symbolic interpretations that scholars link the young man in the garden with the narrative about the young man in the empty tomb in Mark 16:5. Consequently the passage is read by some in terms of the Joseph narrative in Hebrew Scriptures (Gn 39:12). Waetjen (1965) links both Mark 14:51-52 and 16:5 with Joseph, writing that the:

contrast between the fleeing Joseph, who leaves behind his clothes and is unjustly disgraced on the one hand, with the exalted Joseph, who wears splendid garments and is exalted to vice-regent on the other, is matched and reproduced by Mark 14, $51 \mathrm{f}$. and 16, 5 .

(Waetjen 1965:120)

Another popular symbolic interpretation of a similar nature is to link the passage with baptism, ${ }^{7}$ as was recently done by Thorday (2005) who argues that the narrative is to be understood in terms of baptismal education. Then the naked young man in the garden represents the status of the one who is to be baptised and the young man in the tomb reflects a new status acquired in baptism.

From these remarks, it is clear that interpreters follow either a historical or symbolic reading of the young man, as if they are mutually exclusive. But such perspectives may not necessarily be exclusive. In our post-modern context and from the perspective of New Historicism, we have grown accustomed to the view that history in itself is interpretive in nature. It reflects the selection and allocation of meaning given to events by those who record them. Even if the young man is an eyewitness and his story is told in order to stress that events in Jesus' life were observed by his disciples, more reflection is needed on the significance that Mark allocates to him, and to reflect on the role he plays in the Markan narrative. ${ }^{8}$ Before this can be done, the coherence between the two stories about the young man requires more attention.

\section{THE COHERENCE BETWEEN THE TWO}

\section{PASSAGES}

From the above remarks, it has already become clear that some exegetes find a link between the stories of the young man in the garden (Mk 14:51-52) and the young man in the empty tomb (Mk 16:5). This is done, as is shown above, in terms of the context in which the passages are located. The grid which exegetes place on the passages requires that the two need to be read together. Therefore baptism and the Joseph event, as grids, bring the two diverse passages together as one event, because the two facets of the practice of baptism and the history of Joseph overlap with the two separated stories of the young man.

There are, however, indications that the coherence between the two narratives is not a result of an interpretive grid that must be placed on them. Textual information, mostly of a linguistic nature also indicate a coherence between the two passages. There are several arguments for this identification, which need more consideration. ${ }^{9}$

\footnotetext{
7.The problem with this symbolic explanation is that people were not undressed when they were baptised. The image does not really 'fit' baptism.

8.Theissen (1992:197) discusses the passage in terms of the eyewitness status of the young man, the symbolic meaning or typologically, the fulfilment of scripture, concluding, 'Es is nog immer eine offene Frage, worin die erzählerische Funktion cor beiden anonymen Personen gelegen hat. Sind sie wirklich nur Zeugen, Typen der beiden anon' the anonymous persons was. Are they really only witnesses, types or symbols?) Fleddermann (1979:417-418) also discussed different readings of the episode and noted, 'Although, in view of the preceding pericope, a type of the fleeing disciple is perhaps superfluous, the young man, by this reading, represents Mark's judgement on the events, a "signature" summarising his theology' (secondary emphasis).

9.Johnson (1999:178-170) and Thorday (2005) also link the two passages. Johnson does not explain his combination of the two passages, but Thorday provides literary arguments: especially the similar description ('young man'), the motif of 'dressed' and the fleeing away (of the young man and the women and the fin passages are taken passages are taken together, but questions this argument. He finds that 'dressed' is too general a word to resonate with the reader and to recall the previous passage.
}

The coherence of the two passages can be determined in terms of their contents (like shared motifs) and in terms of Mark's literary techniques.

\section{Similarities in contents

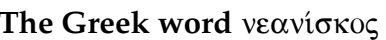

One of the key issues in the interpretation of Mark 14:51-52 has been the reference to the character as a 'young man'

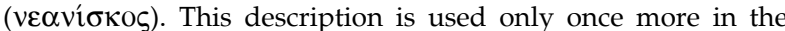
gospel: in the unique narrative about the women's visit to the grave in Mark 16, the person who announces that Jesus is risen is also a young man. This singular reference to the young man is striking, especially when compared to the character(s) of the angels in the parallel versions of the other gospels who are present at the tomb (an angel in Mt 28:2; two men in bright

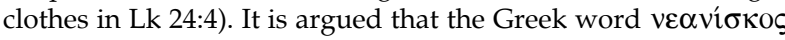
which is used in both instances, is not coincidental and suggests a link between the two passages. Therefore, the fact that both passages in Mark 14:51-52 and Mark 16:5 speak about a young man suggests the possibility that they should be read together.

\section{Anonymity}

Secondly, in both passages, the young man is anonymous. As such, he is one of a small, but significant number ${ }^{10}$ of characters who are not identified in Mark's gospel. Mark's characterisation includes the use of individuals who are not named, but who are significant enough to him to develop his plot. The anonymity of characters has often been noted by scholars and has given rise to various hypotheses. Consequently some have argued that this was 'protective' anonymity, done to protect the identity of the people involved (e.g. Bauckham 2007:194-197; Theissen 1992:197). Whatever the reason, the fact is that both references to the young man fail to identify him. The narrative does not explain his appearance and does not describe any further action on his part. This anonymity of the young man in both instances contributes further to the coherence of the two passages. It can hardly be coincidence that both the young men would be anonymous.

\section{The dress of the young man}

The dress of the young man in the empty tomb has played an important role in the history of interpretation. One of the oftenrepeated arguments against identifying him with the young man in the garden is that his 'white' robe implies that he is an angelic being (e.g. Brown 1994:300). This argument is also linked with the fact that the resurrection narratives in the other gospels speak of such angels at the tomb of Jesus.

But such a reading of the young man in Mark 16 is determined by information outside the text and ignores important inner-Markan arguments which point towards the fact that the two episodes about the young man are about the same person. ${ }^{11}$ Take, for example, the argument that angels are often described as young men in ancient texts (e.g. Brown 1994:304). Consequently, it is argued, the young man as an angel in Mark 16:5 stands in contrast to the ('human') young man in Mark 15:51-52 (Brown 1994; Fleddermann 1979; Vanhoye 1971). Brown (1994) notes,

The Jesus who was abandoned disgracefully by the last disciple and left to face his hour of arrest and death alone is in 16:5-6 served by an 'angel'; who proclaims his victory over death.

(Brown 1994:304, secondary emphasis)

10. There are as many as 14 anonymous characters in Mark out of a total of 40 named characters (depending on how one counts). Cf. the interesting list in http://catholicresources.org/Bible/Mark-People_Places.htm.

11.Brown (1994:296) himself warns against such arguments when he rejects the identification of the young man in Mark 14:51-52 as John, because of information in John's Gospel. 
He therefore sees the young man in the tomb as an angelic figure who does what the young man in the garden did not do. This is a creative proposal. Mark does, however, mention angels elsewhere in his gospel without calling them young men. He, in fact, describes how Jesus is supported after his sojourn in the desert by angels (Mk 1:1), but uses the Greek word oi ö $\gamma \gamma \varepsilon \lambda$ or (cf. also Mk 12:25 \& 13:32). There is no indication in Mark's gospel itself that the young man in the empty tomb should be an angelic being.

The motif of the clothing reinforces the impression that the two episodes form a coherent whole. Mark often mentions clothing with strong symbolic overtones so that it has special significance for him. Consequently the clothes of John the Baptist in Mark 1:6 identify him as a prophet, and, therefore, as an important figure at the beginning of the gospel. The clothing of Jesus in the episode on the transfiguration in Mark 9:3 becomes dazzling white, 'whiter than anyone in the world could bleach them.' The nature of the clothing underlines the mysterious significance of the event. In Mark 14:30-33, the High Priest tore his clothes after Jesus' pronouncement about the Son of Man at the right hand and coming with the clouds.

These references to exceptional clothing are found at crucial points at the beginning and at the turning point of the narrative where important revelations are given. In the episode on John the Baptist in Mark 1:7 there is a reference to the coming one and in the transfiguration narrative in Mark 9:7 the voice from the cloud reveals Jesus as the divine Son to whom his followers should listen. The action of the High Priest also takes place at a seminal moment in the trial of Jesus. In all of these cases, the significance of Jesus is highlighted through the narrative detail of clothing.

The clothing of the young man in Mark 14:51-52 and in 16:5 should be understood against this background. The young man in Gethsemane, according to Mark, is dressed in a linen cloth

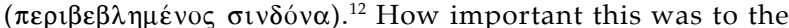
author is clear from the fact that he repeats the reference in the following description of how the young man, having fled naked,

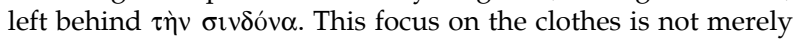
a report of an event, but is also an indication of the significance of the event. In a Jewish context nakedness would be regarded as a shameful state (cf. further below). Mark is implying that the young man, eager to follow Jesus after others fail him, also falls into shame..$^{13}$ His leaving behind his clothes is stressed also by the ensuing and explicit reference to his nakedness.

In Mark $16: 5$ a young man sits on the right, $\pi \varepsilon \rho 1 \beta \varepsilon \beta \lambda \eta \mu \varepsilon ́ v o v$ $\sigma \tau 0 \lambda \eta \dot{v} \nu \varepsilon \varepsilon \kappa \eta \dot{v}$. He also is described by Mark with exactly the same word 'dressed', though this time, the young man wears a white robe. In both cases the clothes are special, as a linen cloth was expensive and the white robe reminds one of Jesus' appearance in the transfiguration scene. The young man is dressed in both cases in a special way. There is, however, also an intensification in the narrative. The young man with his linen cloth - which he loses - contrasts with the young man in the empty tomb who is dressed in a more special manner.

The motif of clothing is being foregrounded because Mark speaks of 'being clothed' and then adding to it the object with which the young man is clothed. It draws attention to the clothes of the young man.

Exegetes who identify the two young men use this motif of clothing to point to the complete reversal of his condition. If the previous dress (in the garden) was the linen cloth, this one in the tomb, however, is white. Though he is dressed in both

12. The normal use of this word in terms of 'dressed' or 'wearing' in Mark 14:51-52 is supported by the similar use of the word in Mark 16:5; cf. Collins (2007:124). The literal sense - having a piece of linen wrapped around himself - is less likely because of the link between the passages.

13.Cf. further the discussion of Mark 5 below. cases, the difference in dress expresses the development within the narrative. The portrayal is therefore characterised by closure: the shameful condition ${ }^{14}$ of the young man as he flees the scene of Jesus' arrest in the nude is replaced by his restoration. What would otherwise be an incomplete narrative if the coherence between two episodes is not understood becomes a coherent picture because of the motif of clothing.

One may even take the comparison further by analysing the type of dress mentioned by Mark. It is often noted that Mark spoke of a linen cloth in which Jesus was buried (Mk 15:46). The linen cloth is mentioned twice in Mark 14:51-52 and in 15:46. In Mark 15:46 Mark again repeats the motif of the linen cloth, emphasising to his readers in what cloth Jesus was buried. In this way Mark's description of clothing reflects the dress of Jesus before his resurrection. Taken together, Mark associates linen clothing with shameful betrayal and with death. The young man in the empty tomb is said to wear a white dress to indicate that he is not simply resuming his earlier lifestyle.

For exegetes who link the episodes, the difference in wording of the dress suggests that the young man who abandons Jesus is found in a different status after the resurrection. ${ }^{15}$ His status, reflected in his white robe, is confirmed by his being seated at the right hand side - a clear contrast to his running away in the garden and an indication of a special role in unfolding events (cf. Lk 24:4; Jn 20:12). In Mark's Gospel sitting on the right is an indication of a special place, as is clear from Mark 10:3940. There is also an intriguing difference between him being accosted in the garden and the alarmed, respectful response of the women to him (Mk 16:5).

\section{First and last}

The significance of the young man in Gethsemane is also determined by his place in the narrative. The episode of the young man in the garden is placed at a seminal location in the gospel. In Mark 14:50, the author notes that after the cutting

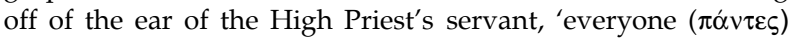
deserted him and fled.' This remark refers to the disciples who have been with Jesus during the night. ${ }^{16}$ Those who are close to Jesus and are known to have been his followers, betray him. With this, the prediction of Jesus in Mark 14:27 is fulfilled - all the disciples will fall away (cf. also Edwards 1989:441).

Not only Jesus' closest associates, but also other disciples fail him. The young man is not merely an interested, curious bystander who happens to observe the unfolding events. Mark describes him with terminology that reminds one of discipleship. He 'was following together' ( $\left.\sigma \cup v \eta \kappa о \lambda \circ v i \theta \varepsilon 1^{17}\right)$. Mark often describes how disciples follow Jesus or wish to follow him after brief contact with him (Mk 1:18, 20; 2:14; 10:17-12, 52). ${ }^{18}$ The passage therefore suggests that the young man has had a special relationship with Jesus (Brown 1994:295-296). But he, too, abandons Jesus ultimately. With this, the betrayal of Jesus is complete: he is utterly alone, abandoned by everyone within and outside of his circle of close companions.

14.Cf. Brown (1994:295), for variants which indicate how early readers struggle with the scandalous nature of the young man's nudity.

15.Myllykoski (2002:61), reading the episode historically, argues that the expression mplies that Jesus was buried in an expensive tomb of an acrosolium-type, which would explain the reference 'at the right side.' Once again the question is would explain the reference 'at the right side.' Once again the $c$ significance Mark allocates to the motif rather than its historicity.

16.Cf. Peace (1999:253-281) on discipleship in Mark; he points out how the disciples fail to understand Jesus and how Mark 16 restores them to discipleship. As they understand Jesus fully only after his death and resurrection.

17. Note, for example, how this compound verb is used in Mark 5:37 to describe the closest followers of Jesus. Cf. also the comments by Vanhoye (1971:404).

18. Bauckham (2007:199) has pointed out that the young man 'would surely not have continued to follow Jesus and his captors after everyone else had fled if he had been motivated by nothing more than curiosity... There is no good reason why he should not have been a supporter of Jesus who accompanied the other disciples to Gethsemane." 
How significant this is, was noted by Brown (1994):

This young man's attempt to follow Jesus into peirasmos' is a miserable failure; for when seized as Jesus had been, he is so anxious to get away that he leaves in the hands of his captors the only clothes he wears and chooses the utter disgrace of fleeing naked - an even more desperate flight than that of the other disciples.

(Brown 1994:303)

He does what the rich man also did when he could not continue with Jesus' demands for discipleship (Mk 10:17-21).

Finally, one should remember that the episode of the young man separates the previous narrative from the trial of Jesus which follows and which represents the climax of the gospel narrative. The young man as the last follower of Jesus to abandon him after all the others have already fled reflects the outcome of Jesus' earthly ministry (Brown 1994:295-296) - once again confirming what Jesus predicted in Mark 14:27. He furthermore represents the new dispensation which was inaugurated by the resurrection as the opposite of the pre-resurrection condition.

The young man in the tomb also has a special place in the narrative in another sense. He is, namely, the first to give witness to Jesus' resurrection. He is well informed about the whereabouts of Jesus and reveals the coming appearance of Jesus to his disciples. He relates what has happened to Jesus, points out the empty tomb and sends a message to the disciples that Jesus has gone to Galilee. He is, moreover, an important figure as a messenger who explains the significance of the empty tomb to the women. Witnessing to Jesus is of seminal importance to Mark. The young man in the tomb gives witness to Jesus in the sense of Mark 1:2. Mark ends his gospel in the same way he began it in Mark 1:2, where he refers to Isaiah's description of the messenger who will prepare the way of the Lord (cf. also Thorday 2005). His appearance, though described rather cursorily, has, as Becker (2007:250) explains, apocalyptic features, which befits his important role. He is a herald of the end-time - of the final moment of triumph.

The effect of Mark's location of the young man's character is to create an inclusio. The last one who has been with and who then abandons Jesus, is also the first one to announce his resurrection..$^{19}$ Mark uses him to frame the story of the cross. In the frame, the implications of the gospel of the cross are spelled out. What this implies must be explained in more depth. But first, some formal considerations regarding the coherence of the two episodes deserve more attention.

\section{Literary coherence}

Mark's literary and compositional approaches further suggest that the two episodes about the young man should be read together. It is therefore necessary that one should look further than mere shared motifs.

\section{Episodal link}

A previous part of Mark's gospel provides indications of how the author composed his narrative in a coherent way. This example will confirm that the author conceived of the two episodes about the young man in terms of two motifs which belong together and which are later worked out in separate narratives. In Mark 14:27-31, Jesus first predicts to his disciples, 'You will all fall away' (Mk 14:27). This motif reflects what Mark reports later on in Mark 14 when the disciples indeed abandon Jesus. Jesus' prediction is explicitly fulfilled in the seminal Mark 14:50. Jesus, however, according to Mark 14:28, immediately adds, 'But after I have risen, I will go ahead of you into Galilee.' The abandonment and the resurrection/Galilee motif are therefore combined. The young man in Mark 16:7 tells the women about the resurrection and asks them to communicate to the disciples that Jesus is on

19. Inclusio is often mentioned as a literary technique with special significance in Mark For example. Peter is the first and the last disciple to be named in Mark's narrative (1:16; 16:7). Cf. for example Bauckham (2007:200). his way to Galilee. Mark 14:27-31 therefore combines what Mark separates into two different episodes about the young man.

\section{The sandwich technique ${ }^{20}$}

More should be said, however, on the link between the two passages about the young man. The link is made more probable because of a recurrent literary technique which the author uses in the rest of his gospel and which is also used here. Mark often interrupts a story by inserting what appears to be an unrelated story in its middle. One of the best examples is found in Mark 5 where the healing of Jairus' daughter is interrupted with the healing of the woman with the haemorrhage..$^{21}$ The technique reveals how Mark links passages and events in a non-sequential manner.

In the case of the young man, the stories about a young man are used as an outer framework for the trial and crucifixion of Jesus, followed by his resurrection. They complement the story of the death and resurrection of Jesus with the story about discipleship and spell out the consequences of Jesus' ministry. The young man in the garden reveals the fragility of discipleship before the death and resurrection. The young man in the empty tomb reveals powerful discipleship as witness after the resurrection of Christ.

\section{THE DEMON-POSSESSED MAN IN MARK 5}

Finally, attention must be drawn to another passage in Mark's gospel which explains both the coherence and the meaning of the two episodes of the young man. Mark's gospel contains another special example of a complete reversal of someone's fate. Mark 5:1-18 is a long passage about the healing of a demon-possessed man in the region of the Gerasenes. Carrying the name Legion, as he himself declares (Mk 5:9), he is a prime example of complete evil. He lives amongst graves - a scandalous existence. His nakedness contributes further to this shameful state. He is out of control; chains and irons could not restrain him. In addition he is also self-destructive, cutting himself with stones (Mk 5:5).

This state of complete evil is challenged when Jesus appears on the scene. When he sees Jesus, he asks Jesus not to torture him and to exorcise the demons. In this, he differs from others who beg Jesus for mercy (e.g. Mk 1:40). Of special significance is that he recognises Jesus as Son of the Most High God - thereby revealing his insight into the true identity of Jesus (Mk 5:7) He therefore understands the power of Jesus more than many other characters in the gospel (e.g. Mk 4:13). What makes the demoniac's address more significant is that he uses the title for Jesus with which Mark begins his text, 'The beginning of the gospel about Jesus Christ, the Son of God' (Mk 1:1). The episode of the demoniac elaborates on this title, explaining that the gospel is about the transformative power of the Son of God. In this way there is resemblance between him and the young man in the garden, who also finds Jesus powerful enough that he wants to follow him, but who turns away from him ultimately. His abandonment of Jesus results in a similar shameful state as that of the demoniac.

It is, however, the radical consequences of Jesus' power, in particular, that are relevant to the episodes of the young man. After he is healed, the people stream to Jesus and see the man

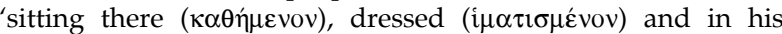
right mind.' His 'sitting' contrasts with his previous state in which no one could subdue him (Mk 5:4). And the reference

20.Cf. Edwards (1989:193-194) for a discussion and for alternative terms for this technique like intercalations, interpolations, framing (or Schiebungen) (in German). He also traces pre-Markan examples of this technique, referring, amongst others, to Homer's lliad and Odyssey and Hebrew scriptures. It is also necessary to compare the literary technique of inclusio to reflect on the repetition of gospe material (cf. e.g. Carson \& Moo 2005).

21.Cf. also Mark 3:20-35; 4:1-20; 5.21-43; 6:7-30; 11:12-21; 14:1-11; 14:17-31; 14:53-72; 15:40-16:8; and further: Edwards (1989:203); Bauckham (2007:196). 14.53-72; 15:40-16:8; and furt 1905 who (1989:203); Bauck am (2007:196). For (Mk 4:3-8) and of the tenants (Mk 12:1-9) are part of complexes of texts which are linked to and finally interpreted by Mark 14:22-25. 
to his dress suggests his previous nakedness. The picture is that of radical transformation from a state of complete evil to becoming a follower of Jesus. This transformation is so powerful that those who observe it 'were afraid' (Mk 5:15). Once again the similarities with the episodes of the young man are striking.

Finally, there is a close relationship between the transformation of the demoniac and discipleship. After his healing, he begs to remain with Jesus, but Jesus refuses and instructs him to give witness in Decapolis about what Jesus has done for him (Mk 5:19). The results of his witness are impressive - all the people

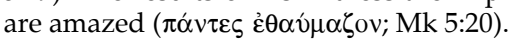

There are similar dynamics at work in the episode of the demoniac in Mark 5 and the two episodes of the young man. First of all, the demon-possessed man undergoes a radical transformation when he meets Jesus. Secondly, the transformation is expressed physically in terms of his clothing and sitting, but clearly with symbolic overtones. Thirdly, he becomes a witness to the power of the Son of God. Physical information about nakedness and clothes illustrates the deformation and the transformative and divine power of Jesus, which heals the antagonistic and the faltering ones, so that they become messengers of the gospel. Finally, the transformation has an effect of amazement on bystanders.

The two passages about the young man reveal similar dynamics: here too, there is deformation, followed by a radical transformation expressed in physical, but symbolic language. The transformation is this case is effected by the resurrection of the crucified One (Mk 16:6). The effect of the transformation is seen in the dress and in the sitting of the young man on the right.

Mark has separated the two episodes about the young man with the story of the cross and resurrection. Mark narrated how the centurion, when he saw 'how' Jesus died, exclaimed, 'Surely, this man was the Son of God' (Mk 15:39). It is the powerful death and resurrection of Christ as Son of God that brings people to find significance in the cross and to understand who Jesus really was. Before his death all those who remained with him, even to the very end, finally abandoned him. After his death, they become witnesses - as the young man himself shows.

\section{THE POWERFUL TRANSFORMATION IN RE-CREATION, LOVE AND GLORY}

Now that the coherence of the two episodes has been explained, more attention has to be paid to the significance and implications of the episode about the young man, especially from the perspective of biblical spirituality. From the above arguments it is clear that there is a strong link between the young man in the garden and the young man in the empty tomb. His story illustrates the radical transformation which is brought about by the death and resurrection of Jesus. It shows how radically he was changed from a disciple who abandoned Jesus, falling into a state of betrayal and shame to someone who gives witness to the resurrection.

Through this contrast between a fallen and restored status, Mark frames the cross and resurrection to make the important point that the cross and resurrection had a complex transformative effect on believers. Edwards (1989) argues that Markan intercalations are more than mere literary techniques. They are applied with a discernible theological purpose. He writes:

the sandwiches emphasize the major motifs of the gospel, especially the meaning of faith, discipleship, bearing witness, and the danger of apostasy. Moreover, I shall endeavor to show that the middle story nearly always provides the key to the theological purpose of the sandwich. The insertion interprets the flanking halves. To use the language of medicine, the transplanted organ enlivens the host material.

(Edwards 1989:196)
Edwards (1989) mentions as an example how Mark placed the Lord's Supper (vv 22-26) between accounts of denial and cowardice to contrast the faithlessness of Jesus' disciples to the covenant faithfulness of God.

We see substantially the same picture with Jesus praying alone in Gethsemane while the disciples sleep, dying alone on Calvary after the disciples have fled. God's salvific covenant depends on his faithfulness, and it stands in spite of the faithlessness of his people.

(Edwards1989:210)

For Edwards (1989:213) Mark 15 is also 'built around the poles of denial (mockery in vv 16-32) and confession (v 39).' This sandwich therefore intensifies the truth of the previous one: the Son of God is faithful and true where his disciples are not, and their failure can only be seen for what it is in light of his suffering righteousness.

What Edwards calls the theological meaning of the episode can better be explained in terms of biblical spirituality. Transformation is a key motif in biblical spirituality, which has to do with the relationship between the divine and humanity which changes humanity (Waaijman 2006a:13-14). Mark wanted to contrast the divine faithfulness with human faithlessness and wanted to point out the transformative effects of God's initiative in the story of the young man.

Transformation is, however, multi-faceted, as this episode illustrates. It, for example, shows how the cross as symbol of the beloved Son's self-giving ministry brings about transformation and leads to discipleship. Ultimately the young man who abandons Jesus becomes the first one to give witness to the crucified and resurrected Son of God because the Son's sacrifice serves as a ransom for many ( $\mathrm{Mk} 10: 45)$. It is therefore a transformation motivated and inspired by divine intervention and brought about by the Son's faithful ministry. The young man in the empty tomb is, furthermore, as follower completely obedient to the divine calling that humanity should witness to God and be fishers of humanity (Mk 1:17-18). He represents the answer to Jesus' calling of disciples as witnesses (cf. Welzen 1995:13).

But there is more to this transformation than merely reflecting the divine nature of and initiative in transformation. The various motifs in the two episodes illustrate how comprehensive transformation is. To understand this better, one has to analyse the notion of transformation in more depth. Waaijman (2006b:42) distinguished five layers of transformation in spirituality which can be summed up as follows, (1) transformation from non-being into being - the creation by God, (2) transformation from being deformed to being re-formed in God's re-creation of man, (3) someone's becoming conformed to a divine-human transformation model which introduces a person into divine reality, (4) transformation in love in which the soul is led into God, while God takes up his abode in the soul and (5) the transformation in glory which awaits us after this life but of which the transformation in love already contains a sketch.

This is a helpful distinction that enables one to recognise different dimensions of the key motif of transformation. This model of transformation is also helpful in understanding the frame of the young man that Mark places on his narrative of the passion and resurrection of Jesus.

It is, for example, clear that the passion and resurrection of Jesus brings about a transformation in re-creation. Waaijman (2006:4344) observes that humanity, having made the transition from non-being into being (transformation in creation), can orientate itself to good or to evil. Where evil prevails, deformity follows. This happens also with the young man in the garden. Mark makes a point of illustrating the shamefulness of his actions as he allows others to destroy his relationship with Christ and as he betrays Jesus. His nakedness represents the way in which his lack of faithfulness brings about his deformation. He follows 
the disciples in their shameful and deformed betrayal of Jesus. The death and resurrection of Jesus, however, brings about his transformation in re-creation from a failed witness and his state of shame into a privileged witness of the resurrection. ${ }^{22} \mathrm{He}$ himself has no part in his re-creation. His transformation is a divine gift to him which grants him a totally new condition and status.

This is, at the same time, a transformation in love and in conformity with Christ. The young man has become a disciple in the fullest sense of the word. He has been reunited with Christ, fully aware and informed of who he is. He shares with the women information no one else was aware of. He becomes the example of faith as understanding which has been lacking in the predecing narrative. What happens to the young man, goes back to the earliest phases of Christ's journey. In Mark 1:9-12 Jesus is portrayed as having had a mystical experience when the heaven opened and he is addressed as the 'beloved' Son. The intimate relationship with the Father is here expressed through the key word of love. After this mystical experience which transforms Jesus to become the suffering Messiah, Jesus begins to proclaim the gospel (Mk 1:15) and to call disciples to follow him in this task. Jesus thus gathers followers who share his call and his task.

Mark reinforces this insight when he refers to a similar mystical experience in the transfiguration (Mk 9:2-12) where the Son is once again described as the 'beloved' one. In this episode Christ is portrayed as the one who has a hidden, but glorious identity. He is literally transformed into a divine form when his clothing becomes white (cf. esp. Welzen 1995). God is acting in him as the divine son who has an intimate relationship with God as his Father (Mk 14:36). This divine son who was earlier presented as the proclaimer of the gospel of the end time which his disciples must also proclaim (Mk 1:1, 15, 17-18), is again presented to them as the Son - but this time as the one to whom his disciples should 'listen' (Mk 9:7). This also promotes the understanding the ministry of Jesus as closely linked with discipleship.

It is against this background that one should understand the transformation of the young man. When in Mark 16:5 the young man is present as witness in the empty tomb, he acts conform to the ministry of Christ and thus heeds the call to witness. He becomes what Christ was. What is intriguing, furthermore, is that he does so in the absence of Christ. He witnesses where Christ is not present, showing how the the divine is being revealed also in the witness of believers. The young man 'is following someone who is not there,' becoming a Christ-like figure and thus one who is transformed into conformity with Christ..$^{23} \mathrm{He}$ becomes a follower just like the demon-possessed man who was denied his wish to remain in the presence of Jesus and who obeyed Jesus' instruction to give witness to others in Decapolis.

There is, however, more to the transformation of the young man. It is also a transformation in glory. Waaijman (2006) wrote,

Transformation in love occurs in this life; transformation in glory belongs to the life after this life. About that, we as yet know nothing. We only catch a glimpse of to the degree that our transformation in love contains a sketch of the transformation in glory.

(Waaijman 2006:46)

Mark knows this type of transformation, as is clear in his pronouncement about the Son of man who 'comes in his Father's glory with the holy angels' (Mk 8:38-9:1). But for Mark this

22. Thorday (2005) communicates some of this in his observation that the disciples are characterised by 'unredeemedness', on the one hand and on the other, that the young man dressed in a white robe appears as the messenger of redemption. The young man in Mark 14:50-52 foreshadows the passion and death of Jesus by the sign of being stripped naked in the human and spiritual sense. In Mark's desiption of the of the discipe aning the disciples to have the courage to live the fullness of the Easter mystery.

23.See the salient remarks by Welzen (1995:101) transformation in glory is not only a matter of the future. The young man in the empty tomb displays glorious, physical signs of this transformation in glory - he wears a white robe and sits on the right side as signs of a special favour. His appearance reminds one of Christ's appearance during the transfiguration. The special state of the young man is evident from the fact that the women are alarmed by him, aware that they are experiencing a divine mystery (Mk 16:8). The eschatological status of believers as having been glorified already in the present, evident throughout the New Testament, is therefore evident in this episode as well. Faith means that one lives in the divine presence in such a way that it permeates one's being and empowers one to a new way of life already in the presence. It is a new life which, though present in a hidden manner, gives an indication now already of the future power and glory of the kingdom. ${ }^{24}$

The story of the young man in Mark's Gospel spells out the powerful consequences of Christ's ministry, especially as it culminates in his death and resurrection. Those who respond to the divine call, Mark tells his readers, will experience times of unfaithfulness and even betrayal. And yet, the divine power will transform them to remain close to God, to live in conformity with Christ and to experience a completely new and fulfilling way of life.

\section{REFERENCES}

Bauckham, R., 2007, Jesus and the eyewitnesses. The Gospels as eyewitness testimony, Eerdmans, Grand Rapids.

Becker, E.-M., 2006, Das Markus-Evangelium im Rahmen antiker Historiographie [The Gospel of Mark within the framework of ancient historiographyl, Wissenschaftliche Untersuchungen zum Neuen Testament 1.194, Mohr-Siebeck, Tübingen.

Blaiklock, E.M., 1967, Mark: The man and his message, Moody Press, Chicago.

Brown, R., 1994, The death of the Messiah, vol. I, Doubleday, New York.

Carson, D.A. \& Moo, D.J., 2005, An introduction to the New Testament, Zondervan, Grand Rapids.

Collins, A.Y., 2007, 'The flight of the naked young man revisited', in J.E. Aguilar Chiu, F.M. Filippo Urso \& C.Z. Estrada (eds.), Il Verbo di Dio è vivo, Analecta Biblica 165, pp. 123-137, Pontifical Biblical Institute, Rome.

Edwards, J.R., 1989, 'Markan sandwiches: the significance of interpolations in Markan narratives', Novum Testamentum 31(3), 193-216.

Fleddermann, H., 1979, 'The flight of a naked young man (Mark 14:51-52)', Catholic Biblical Quarterly 41, 413-414.

Haren,M.J.,1998,'Thenaked young man: Ahistorian'shypothesis on Mark 14, 51-52', Biblica 79, 525-531.

Johnson, L.T., 1999, The writings of the New Testament: An interpretation, Fortress, Minneapolis.

Klostermann, E., 1950, Das Markusevangelium [The Gospel of Mark], Mohr, Tübingen.

Lane, W.L., 2002, The Gospel according to Mark, New International Commentary on the New Testament, Eerdmans, Grand Rapids.

Myllykoski, M., 2002, 'What happened to the body of Jesus?' in H.I. Räisänen, C. Dunderberg, C.M. Tuckett \& Kari Syreeni (eds.), Fair play: Diversity and conflicts in early Christianity: Essays in honour Heikie Räisänen, pp. 43-82, Brill, Leiden.

Peace, R., 1999, Conversion in the New Testament. Paul and the twelve, Eerdmans, Grand Rapids.

24.See also the remarks of Welzen (1995:13-14). He describes the visionary experience of the three disciples in which they experienced the white clothes as indication of the 'metamorphosis' of Jesus which represents the breakthrough of a transcendent reality. 
Saunderson, B., 1989, 'Gethsemane: the missing witness', Biblica 70, 224-233.

Schweitzer, E., 1968, Das Evangelium nach Markus [The Gospel according to Mark], Vandenhoeck \& Ruprecht, Göttingen.

Theissen, G., 1992, Lokalkolorit und Zeitgeschichte in den Evangelien: ein Beitrag zur Geschichte der synoptische Tradition, [Local colouring and 'Zeitgeschichte' in the Gospels: a contribution to the history of the synoptic tradition], Vandenhoeck \& Ruprecht, Göttingen.

Thorday, A., 2005, 'The role of the Neaniskos in the Easter Mystery according to Mark', Sacra Scripta (1-2), 63-72.
Vanhoye, A., 1971, 'La fuite de jeune home nu (Mc 14, 51-52) [The flight of the naked young man]', Biblica 52, n.p.

Waaijman, K., 2006a, 'What is spirituality?' Acta Theologica Supplementum 8, 1-18.

Waaijman, K., 2006b, 'Conformity in Christ', Acta Theologica Supplementum 8, 41-53.

Waetjen, H., 1968, 'The ending of Mark and the Gospel's shift in eschatology', Annual of the Swedish Theological Institute 4, 116-120.

Welzen, H., 1995, 'An initiation into mystical life: The gospel according to Mark', Studies in Spirituality 5, 86-103. 